\title{
Re-Imagining Normativity: The Role of the Imagination in Linguistic Communication
}

\author{
By BARBARA FULTNER \\ Denison University, USA
}

\begin{abstract}
I argue that linguistic competence and communication are best understood as requiring sensitivity to both normativity and creativity. Yet most mainstream (analytic) accounts of meaning tend to focus on problems of normativity rather than creativity. Phenomenology offers a corrective to this imbalance because of its emphasis on embodiment and intersubjectivity, as well as the role it accords to the imagination. I begin by contrasting an account of rule-following that excludes the imagination with one that appeals to Kant's schematism and show that the schematic imagination makes possible a "seeing-as" that plays a key role in rule-following. I then use Gadamer's hermeneutics to articulate a notion of creative imagination. Finally, I turn to Merleau-Ponty's account of embodied imagination to fill out a conception of language as not only a lived but also an inherently embodied practice.
\end{abstract}

\section{Introduction}

Most mainstream analytic accounts of linguistic or semantic meaning tend to be overly rationalistic or cognitivist, focusing on denotation rather than connotation, representation rather than affect. They also tend to focus on problems of normativity rather than creativity (or, in a tradition going back to Chomsky, to explain linguistic creativity in terms of semantic normativity). Phenomenology offers a corrective because of its emphasis on embodiment and the role it accords to the imagination. In this essay, I argue that linguistic competence is best understood as requiring sensitivity to both normativity (as exemplified in the rule-following debate) and creativity (imagination). On 
the one hand, language is governed by conventions and, on the other hand, individuals can use language to express themselves in creative and novel ways. The imagination is clearly what makes the latter possible. Moreover, I will suggest that rule-following itself involves the imagination. Thus, one might say that linguistic competence is of necessity imaginative and that communication involves both understanding and imagination.

In section 1, I consider why rule-following might be seen to reflect a lack of imagination, using Philip Pettit's solution to the rule-following paradox as an example. I contrast this approach with one that places greater emphasis on contextual understanding of meaning and linguistic creativity, thus bringing the imagination back into play. In sections 2-4, I distinguish between three types of imagination: schematic, creative, and embodied.

a) Schematic imagination. For Kant, the schematism is performed by the imagination and mediates between perception and conception, as Kathleen Lennon, among others, has argued ${ }^{1}$. I believe a similar case can be made for the mediation between two interlocutors. Specifically, schematization, that is, the imagination's act of "seeing-as", plays a key role in communication because reaching mutual understanding requires interlocutors to have a sense of each other's perspective. They must be able to see things otherwise than from their own subjective point of view. Imagination hence plays an important role in the development of intersubjectivity.

b) Creative imagination: The tension between normativity and creativity manifests in Gadamer's hermeneutics as a tension between an individualizing tendency (epitomized in poetry) and conventionalizing tendency in language. I briefly illustrate how the mutual understanding attained in dialogue relies on interlocutors not only knowing the conventions or rules governing language, but also creating new meanings. In addition, for Gadamer, to understand a language is to live it. Thus, language is a practice.

c) Embodied imagination: Language should be conceived not only as a practice, but as an embodied practice. I therefore draw on Merleau-Ponty's embodied account of the imagination in order to flesh out i) how the Gadamerian tension between individualization and conventionalization in language is rooted in the "to and fro movement between acquired and creative modes of embodiment" 2 and ii) how perspective-taking in dialogue

1 Kathleen Lennon, "Re-Enchanting the World: The Role of Imagination in Perception", Philosophy: The Journal of the Royal Institute of Philosophy, vol. 85, $\mathrm{n}^{\circ} 333$, p. 375-389.

2 James B. Steeves, "The Virtual Body: Merleau-Ponty's Early Philosophy of Imagination", Philosophy Today, 2001, p. 370. 
involves acts of imagination. Merleau-Ponty's notions of the body schema and the virtual body are important for both (i) and (ii).

The turn to phenomenology is thus indispensable for providing a unified account of the role of the imagination in communication and intersubjectivity. Only by turning to phenomenology and incorporating the imagination into our theory of communication is it possible to offer a better account of rule-following and of linguistic competence more generally.

\section{Normativity without Imagination}

"Imagination, a licentious and vagrant faculty, unsusceptible of limitations, and impatient of restraint, has always endeavoured to baffle the logician, to perplex the confines of distinction, and burst the inclosures of regularity."1

Samuel Johnson's gloss on the imagination indicates why we might take it to be the polar opposite of rules and normativity. Rules tell us what is right; the imagination tells us what is possible ${ }^{2}$. Normativity is about constraint; imagination is about freedom. Social norms, for instance, have the power to control and regulate our actions, and some political theorists these days turn to the imagination when asking how to escape or change these norms when they are (or we perceive them to be) oppressive or otherwise misguided. Semantic norms or rules constitute meanings governing how we use linguistic terms; and metaphor, poetry, and other imaginative uses of language create new meanings. There is thus a tension between conforming to rules based on convention (normativity) and breaking such rules and generating new meanings (imagination), a tension inherent in language as well as in social action more broadly understood.

The thesis that meanings are normative, i.e. that they function as rules that indicate correct use, may be seen to run counter to the view that language is creative and fosters the imagination. Philip Pettit in Rules, Reasons, and Norms, for example, suggests that part of the solution to the rule-following problem (how does a rule determine its applications?), namely, that a finite set of examples exemplifies a (more or less) determinate

\footnotetext{
${ }^{1}$ Samuel Johnson, The Rambler 1, quoted in Nathan Tierney, Imagination and Ethical Ideals, Albany SUNY Press, 1994 (http://0-www.netlibrary.com.dewey2. library.xxxxx.edu/Reader/, May 12, 2008).

${ }^{2}$ Shaun Nichols, "Introduction," to Shaun Nichols (ed.), The Architechture of the Imagination, Oxford, Oxford University Press, 2006, p. 2 (http://ebooks.ohiolink. edu/xtf ebc/view?docId=ei/ox/978019927573).
} 
way of going on for subjects may "reflect a lack of imagination ... on the parts of those subjects...". . For Pettit, it's an off-the-cuff remark, yet Saul Kripke's (in)famous sceptical challenge to rule-following to which Pettit is responding ("quus" vs. "plus") is nothing if not a feat of imagination. It is not unreasonable to think of at least some failures to follow rules, to break with conventions, as exercises in imagination. I argue that the imagination works at multiple levels relative to normativity. It plays a role in rule-following itself as well as in semantic innovation. The tension between imagination and normativity is hence a dialectical one. What interests me, however, is not so much the sceptical challenge as the ways in which imagination seems to liberate us from norms - or at least (and perhaps as importantly) from narrow (determinate) interpretations of them, and ways in which rulefollowing or meanings/concepts themselves must allow for freedom in application.

Pettit's account of rule-following purports to be a straight solution to Kripke's sceptical challenge. He defines rules as "normative constraints which are relevant in an indefinitely large number of decision-types" ${ }^{2}$. That is, they identify "one option ... as more appropriate in some way than the others" 3 and apply to situations a rule-follower may never have encountered before. For Pettit a rule must also be determinable (i.e. identifiable) "by a finite subject independently of any particular application" - since different subjects will have been exposed to different sets of examples - and "directly readable". That is, they should not stand in need of interpretation. As Wittgenstein says, we follow rules "blindly". It is no doubt this blindness that bespeaks the lack of imagination. Finally, a rule must be "fallibly readable". That is, it is inherent in the nature of rules - i.e. in the nature of normativity - that we might get it wrong. (This distinguishes norms from natural laws.)

Pettit claims to solve the rule-following problem in four steps. (1) Kripke's sceptic famously takes up Wittgenstein's purported paradox that "no course of action could be determined by a rule, because every course of action can be made out to accord with the rule" 4 . To address this, Pettit

\footnotetext{
${ }^{1}$ Philip Pettit, Rules, Reasons, and Norms, Oxford, Oxford University Press, 2002, p. 4 (emphasis mine).

${ }^{2}$ Philip Pettit, "The Reality of Rule-Following,", in Alexander Miller and Crispin Wright (eds.), Rule-Following and Meaning, eds., McGill Queens University Press: Montreal, 2002, p. 199. Originally published in 1990.

${ }^{3}$ Ibid., p. $189-190$.

${ }^{4}$ Ludwig Wittgenstein, Philosophical Investigations, Blackwell, Oxford, 1958, §201.
} 
distinguishes between a finite set of examples instantiating a rule and exemplifying a rule. Whereas the examples instantiate an indefinite number of rules, they may exemplify just one rule for a particular agent. (2) He takes it that we learn rules by ostension. The exposure to a set of examples produces in us a disposition or inclination to go on from these examples in a certain way. This disposition by itself, as Kripke drives home again and again, is not enough to warrant my thinking that I'm going on the right way (i.e. following a rule). That is, one either has or does not have a disposition and it is not the sort of thing that can underwrite normativity. However, Pettit argues that "the inclination in following a rule may have a dual function, serving not only to prompt the agent's responses, but also to make salient the rule she intends to follow: the rule which, given the inclination they engender, a certain set of examples can exemplify". (3) He argues that the rule is a posteriori and contingently related to my inclination "as that rule which fits my inclination but only so far as certain favourable conditions are fulfilled". I may discover that such favourable conditions were not fulfilled and that I got the rule wrong. The way in which I may discover this is by recognising, for instance, differences between how I respond and how others (or my previous selves) respond ${ }^{1}$.

Pettit's account is contextualist in its reference to a particular agent and intersubjective in its reference to interaction with others. The latter is made explicit in one of the three corollaries he identifies: rule-following, he claims, is interactive in that it involves my interactions with myself or other persons ${ }^{2}$. However, while getting it right depends on social interaction and - at least sometimes - the judgment of others, what I do when I take myself to be following a rule is acting on an inclination and hence, acting automatically, blindly, unimaginatively ${ }^{3}$. Perhaps another mark of a lack of imagination is the kind of social conformism Pettit's solution to the rulefollowing problem assumes. For if my discovery of unfavourable conditions (i.e. that I am not following the rule correctly) stems from discovering that I do not respond as others do, this in effect privileges their responses over mine.

\footnotetext{
${ }^{1}$ Ibid., p. 197-200.

${ }^{2}$ The other two corollaries are more directly related to the fallibility of rulefollowing, namely, that rule-following is "precarious" in the sense that I can never "fully redeem" the assumption "that the standardised inclination picks out a unique rule for me to follow" (p. 204) and that rules are relative inasmuch as we cannot rule out the possibility of some later divergence revealing that conditions that I deemed favorable were in fact not.

${ }^{3}$ And that, in Pettit's assessment, is a good thing.
} 
Insofar as there is a discussion of the ability to diverge from norms in Pettit, it is couched in terms of error rather than innovation. The fact that rule-following is based on a disposition or inclination to respond in a certain way makes it unimaginative. Of course, the rule-following debate is about doing justice to normativity and the role of conventions in social practice. "Imagination" is listed neither in the index of The Common Mind nor Rules, Reasons, and Norms. This is not surprising inasmuch as Pettit seeks to do justice to the fact that our rule-following is inherently fallible: we can always get it wrong. He offers a cognitive account, and the imagination is routinely associated with non-discursive thought and with affect. The "failure of imagination" Pettit casually mentions is not intended in any technical sense. But he does not address the ways in which norms are subject to critique. Recognising in hindsight that conditions under which we took ourselves to be following a rule were in fact not, that is, recognising that we followed a rule incorrectly is not the same as recognising that we've followed the wrong rule.

Yet the line between error and innovation is not always clear. How can we differentiate between mistakes and innovations? Donald Davidson, for instance, suggests that we cannot. Perhaps the mistakes that "stick" turn out to be innovations? Recently, furthermore, there has been increasing interest in the interaction of reason and emotion and imagination in moral philosophy as well as in the philosophy of psychology. On one hand, people seek to make reason and cognition more imbued with imagination (e.g. Damasio); on the other hand, people are also developing a more cognitive understanding of the imagination (e.g. Nussbaum, Nichols). In the remainder of this essay, I reexamine the relationship between normativity and imagination in a similar vein.

\section{Schematic Imagination: Seeing-As and Seeing Otherwise}

A counter-veiling current to the emphasis on normativity and conventionality of social practice (and of meaning) can be found in the work of Jacques Derrida, Hans-Georg Gadamer, Donald Davidson, Paul Ricœur, and Judith Butler. They all argue that meaning is determined by context and, to put it more radically, a word or phrase never means (exactly) the same thing twice (polysemy). Think of Derrida's critique of Searle or, of course, the notion of différance, Butler's work on citationality, Davidson's discussions of malaprops and his privileging of the individual over the social aspects of 
meaning, or Ricœur's analysis of metaphor ${ }^{1}$. One might extract from their views that rule-following is in fact always an exercise in using one's imagination in the sense that to follow a rule, to use or understand a meaning is always an exercise in creativity. This thesis finds support in Kant's treatments of imagination and specifically in his notion of schematic imagination.

In Imagination and Ethical Ideals, Nathan Tierney writes that the imagination "resists reduction to more familiar notions" concept of "schematic imagination, to be distinguished both from conceptualization (i.e., abstract thinking through general concepts) and mental imaging"3. Kathleen Lennon draws a similar connection between imagination and perception ${ }^{4}$. Tierney's starting point is Wittgenstein's notion of "seeing-as" paradigmatically exemplified by the duck-rabbit figure. When we look at the duck-rabbit, what occurs is an amalgam of perceptual experience and conceptual thought. This characterization, of course, lends itself extremely well to the application of the Kantian schematism performed, according to the Critique of Pure Reason, by the imagination ${ }^{5}$. The schematism mediates between perception and conception; "seeing-as is the act of schematization"6. According to Tierney, "The schematism structures meaning by mediating between the concrete level of perception (understood in the wide sense to include not merely sensory perception, but situational perception - e.g., 'I see that you are upset') and the abstract level

\footnotetext{
1 Jacques Derrida, Limited Inc., Evanston (IL), Northwestern University Press; Donald Davidson, "A Nice Derangement of Epitaphs," in Truth, Language, and History, Oxford, Oxford University Press, 2005; Judith Butler, Excitable Speech, New York, Routledge, 1997; Paul Ricœur, "Word, Polysemy, and Metaphor: Creativity in Language," in Mario J. Valdés (ed.), A Riccur Reader: Reflection and Imagination, Toronto, University of Toronto Press, 1991.

${ }^{2}$ Nathan Tierney, Imagination and Ethical Ideals, op. cit., p. 43.

${ }^{3}$ Ibid., p. 44.

4 Kathleen Lennon, "Re-Enchanting the World: The Role of Imagination in Perception," Philosophy: The Journal of the Royal Institute of Philosophy, vol. 85, $\mathrm{n}^{\circ} 333$, p. 380 .

${ }^{5}$ According to Kant, a schema [of the concept of understanding] is the formal and pure condition of sensibility and is produced by the imagination. The schematism refers to how the understanding processes these schemata. Schema is thus different from an image [Bild] because the synthesis of the imagination aims at unity in the determination of sensibility. See Immanuel Kant, Kritik der reinen Vernunft, Berlin: Akademie Verlag, 1998, A140/B179.

${ }^{6}$ Nathan Tierney, Imagination and Ethical Ideals, op. cit., p. 57.
} 
of conception"1. Moreover, schemas are "contextually grounded" ${ }^{2}$. I may see a rabbit in one context, but a duck in another.

Tierney's main interest is imagination in ethics. He writes,

if the schematism structures meaning by discovering a fit between perception and conception, and conception is prototypically organized, then moral learning may occur more profoundly through the incorporation into the self of exemplars and examples that fit that prototype than through the learning and application of moral rules ${ }^{3}$.

Note the similarity to Pettit's claim that a finite set of examples exemplifies a rule to an individual and that rules are learned primarily by ostension. Moreover, inasmuch as that the mystery of rule-following stems from how we are able to mediate between abstract rule and concrete applications, the schematism - because of its mediating role between concrete and abstract (category and intuition in Kant) - is the right kind of mechanism to accomplish this. If this is right, then we need the imagination in order to account for our ability to follow rules. We might then respond to Kripke's challenge that responding in accordance with the rule for quaddition rather than addition is not a matter of interpreting differently, but of seeing the problem as a quaddition (rabbit) rather than an addition (duck) problem ${ }^{4}$. (Recall here Pettit's solution in terms of exemplification; on the present account, what it takes for the rule to be exemplified by a particular instance of its application is for the rule-follower to see it as an example of that rule). This also does justice to Wittgenstein's claim that the solution to the rulefollowing paradox is to recognise that there is a way of grasping the rule that is not an interpretation. In this way, the imagination allows us to see things differently.

${ }^{1}$ Ibid., p. 50.

${ }^{2}$ Ibid., p. 57.

${ }^{3}$ Ibidem.

${ }^{4} \mathrm{I}$ 'm unsure that Tierney would approve of this move since he takes schemas (and ideals) to follow a different logic than principles (rules): "Ideals are not principles. Principles are general imperatives of right behavior. 'Do not kill' expresses a principle; 'the end of war on our planet' expresses an ideal. 'Provide for your family' expresses a principle; 'a house in the suburbs for my family' expresses an ideal. Principles and ideals have different logics. Principles are conceptual and universalizable. Ideals are schematic and tied to the aims of the concrete self. Although they may be shared, ideals are not universalizable. From the fact that one person holds an ideal, it does not follow that he thereby prescribes that all persons hold that ideal" (Nathan Tierney, Imagination and Ethical Ideals, op. cit., p. 60). 
The thesis also fits with the idea of associating seeing-as with a background context against which certain features of a situation become salient: I'm more likely to see the figure as a duck against the background of a pond, as a rabbit against the background of a carrot patch. The imagination has been characterized as the faculty that allows us "to see things otherwise". If it allows us to see things otherwise, the current proposal is that it also allows us to see things the same.

The ability to see things otherwise is important for communication in another way. Gregory Currie and Ian Ravenscroft define the recreative imagination as the capacity that underpins perspective-shifting and distinguish it from the creative imagination that involves innovation contrary to expectation or convention ${ }^{1}$. While I cannot do justice to their rich account of the imagination here, it is worth noting that perspective-taking as well as sensitivity to novel contexts are key aspects of linguistic and communicative competence and hence surely bear on the question of semantic normativity and rule-following. An account of perspective-taking will also help address the issue of social conformism raised above, and I will return to it, albeit briefly, later. Now I want to return to the tension between normativity and imagination with which I began in order to flesh out a notion of creative imagination.

\section{Creative Imagination: Poetry and Dialogue}

For Hans-Georg Gadamer there is a tension in language between an individualizing and a conventionalizing tendency, which maps nicely onto the tension between the imaginative and the normative. Like Wittgenstein, he rejects the possibility of a private language, but perhaps unlike Wittgenstein and certainly unlike Pettit, he rejects an absolutely conventionalized language as well. The rules of the latter kind of language would be followed blindly and automatically, but that would undermine the expressiveness of language. He writes,

Someone speaking a private language that no one understands does not speak at all. Yet on the other hand, someone who only speaks one language the conventional nature of which in vocabulary choice, syntax, and style has become absolute, loses the power of address and of evocation which is

\footnotetext{
${ }^{1}$ Gregory Currie and Ian Ravenscroft, Recreative Minds, Oxford, Oxford University Press, 2002, p. 9.
} 
accessible only by means of the individualization of the linguistic vocabulary and other linguistic means ${ }^{1}$.

Absolute conventions may be necessary for technical vocabulary, though there, too, terminology may become so specific as to be untranslatable ${ }^{2}$. Gadamer is thus a contextualist about meaning. Yet whereas thinkers like Derrida, Davidson, or Butler emphasize the contingent and uncontrollable aspects of context, Gadamer recognizes a speaker's (artist's) agency in this process. This intentional semantic creativity is exemplified paradigmatically in poetry. (A similar trajectory can be found in Ricœur's work.) latable.

To the extent that language is unique and individual, it is untrans-

The untranslatability that marks the extreme case of lyric poetry so that it cannot be translated from one language into another at all without losing its entire poetic expressiveness [or illocutionary force] (Sagkraft), clearly implies the failure of the idea of substitution, of replacing one expression by another. This seems to hold more generally, independently of the special phenomenon of highly individualized poetic language. If I'm right, substitutability runs counter to the individualizing moment in language (Sprachvollzug) as such ${ }^{3}$.

Gadamer argues that poetry is the most individualized - yet presumably still intelligibile - form of language since, by its very nature, there is but one right word or way of putting it. To the poet, terms that may seem synonymous (e.g. "home" vs. "abode") are not in fact mutually substitutable (as a referential theory of meaning would suggest). Gadamer holds that the difference between terms is not merely an aesthetic but a semantic one (Sinndifferenz) ${ }^{4}$. Hence he believes that meaning (or reference) is not a purely cognitive, rational, or denotative value, distinct from conative or connotative aspects of communication. Moreover, equivalence relations among expressions are "not unchanging mappings; rather they arise and atrophy, as the spirit of the times is reflected from one decade to the next in semantic change" 5 . Language is a living thing - a thing that we live: "True speaking is more than choosing the means to attain certain communicative

\footnotetext{
${ }^{1}$ Hans-Georg Gadamer, "Semantik und Hermeneutik", in Gesammelte Werke, vol. 2, Tübingen, Mohr Siebeck, 1999, p. 176.

${ }^{2}$ Gadamer uses the example of the term Kraft in German Romanticism.

${ }^{3}$ Hans-Georg Gadamer, "Semantik und Hermeneutik", art. cit., p. 177.

${ }^{4}$ Ibid., p. 175.

${ }^{5}$ Ibid., p. 176-177.
} 
goals. The language one masters is such that one lives in it"1 . And that is to say that language and meaning are always tied to other human practices. While poetry represents the paradigm of individualization, Gadamer says that intended meaning (Sinnmeinung) develops in the course of speaking, in the course of substituting expressions for one another. Conversation takes the form, as Gadamer puts it, of a "fluid uniqueness". By locating the true nature of language (the "productivity of speech") in dialogue, Gadamer rejects strict conventionalism. In conversation with one another, we are able to communicate without having to rely on rigid systems of rules that govern how to make correct and incorrect distinctions ${ }^{2}$. By the same token, he does not deny that there are linguistic conventions and semantic rules - i.e. constraints on how we use terms. Recall that he says that to speak a purely private language, incomprehensible to anyone, is not to speak at all. Yet Gadamer takes this tension between the individual/imaginative and the conventional/ normative to be emblematic of language. Innovations can occur only against the background of an existing and on-going linguistic practice, which in turn is kept alive by innovation. This means, in effect, that normativity and imagination are each a condition of possibility for the other.

\section{Embodied Imagination: Intercorporeality}

The reference to language as a living practice invites a natural transition to Merleau-Ponty. For if language is a living practice, it makes sense that it is an embodied practice as well. In the remainder of this essay, I will (i) use Merleau-Ponty's embodied account of the imagination in order to flesh out (ii) how the Gadamerian tension between individualization and conventionalization in language is rooted in the "to and fro movement between acquired and creative modes of embodiment" ${ }^{\prime 3}$ and (iii) how perspective-taking in dialogue involves acts of imagination.

(i) Although, as others have noted ${ }^{4}$, there are few explicit references to the imagination in especially the early Merleau-Ponty, I take him to give a radically embodied twist to the Kantian account of the schematic imagination that I discussed above. That is, the unity of the manifold of perception that,

\footnotetext{
${ }^{1}$ Ibid., p. 178.

2 Hans-Georg Gadamer, "Vielfalt der Sprachen", in Gesammelte Werke, vol. 8, Tübingen: Siebeck, 1999, p. 345.

${ }^{3}$ James B. Steeves, "TheVirtual Body", art. cit., p. 370.

${ }^{4}$ Ibid., p. 371.
} 
for Kant, is produced by the schematism, is, for Merleau-Ponty, achieved by the body. He argues that there is a synthesis of one's body of what cognitive scientists call synesthesia or multimodality. In our lived experience, we do not need to translate our tactile sensations into visual ones or find a third medium that would render them commensurable. Rather, our very body synthesizes these different experiences (one might even say different sets of sensory data) into our unified lived experience.

Cette traduction et cet assemblage sont faits une fois pour toutes en moi: ils sont mon corps même. ... le corps propre nous enseigne un mode d'unité qui n'est pas la subsomption sous une $1 \mathrm{oi}^{1}$.

We - embodied beings - are what holds together our arms and legs, what simultaneously sees and feels them. This general synthesis of the body is accounted for in terms of habit.

À vrai dire, toute habitude est à la fois motrice et perceptive parce qu'elle réside ... entre la perception explicite et le movement effectif, dans cette fonction fondamentale qui délimite à la fois notre champ de vision et notre champ d'action ${ }^{2}$.

It is through these habits of how we move and how we perceive that, as Merleau-Ponty puts it, we acquire a world. The synthesis need not be confined to what we might call our biological body. Anticipating contemporary theories of extended cognition (many of which take inspiration from him), Merleau-Ponty uses the example of a blind person using a cane, which is not an object she perceives, but an instrument with which she perceives. Indeed, he says, it is really an appendage of her body, an extension of bodily synthesis ${ }^{3}$. He concludes that the body is not an object for an "I think" but a set of lived meanings (ensemble de significations vécues) ${ }^{4}$.

\footnotetext{
${ }^{1}$ Maurice Merleau-Ponty, La Phénoménologie de la perception, Paris: Gallimard, 1945, p. 175. Subsequent citations as $P d P$.

${ }^{2} P d P$, p. 177.

${ }^{3} P d P$, p. 178 . This is a point Merleau-Ponty takes up again in "Eye and Mind" when he says that "our organs are not instruments; on the contrary, our instruments are added-on organs" (Maurice Merleau Ponty, "Eye and Mind," in Galen A. Johnson (ed.), The Merleau-Ponty Aesthetics Reader: Philosophy and Painting, Evanston, Northwestern University Press, 1993, p. 138).

${ }^{4} P d P$, p. 179.
} 
Bodily synthesis is anticipated in Merleau-Ponty's discussion of the body schema earlier in The Phenomenology of Perception:

[M]on corps tout entier n'est pas pour moi un assemblage d'organes juxtaposés dans l'espace. Je le tiens dans une possession indivise et je connais la position de chacun de mes membres par un schéma corporel où ils sont tous enveloppés... l'unité spatiale et temporelle, l'unité intersensorielle ou l'unité sensori-motrice du corps est pour ainsi dire de droit qu'elle ne se limite pas aux contenus effectivement et fortuitement associés dans le cours de notre expérience, qu'elle les précède d'une certaine manière et rend possible leur association. ... [le schéma corporel est] une prise de conscience globable de ma posture dans le monde intersensoriel... et "le schéma corporel" est finalement une manière d'exprimer que mon corps est au monde ${ }^{1}$.

But where, one might ask, does imagination enter the picture? First, our embodiment circumscribes possibilities of our experience. For example, our embodied way of being in the world means (implique) that we experience the world in terms of up-down, left-right, front-back. The body schema provides "potential modes of embodiment", , but it can also be "reorganized" 3 . This reorganization, I submit, is a creative one.

(ii) Acquired and creative modes of embodiment. According to Steeves,

"[a]n essential aspect of the body schema is what Merleau-Ponty calls the 'virtual body' (le corps virtuel)..., an imaginative dimension of embodied existence. The body consists of a dialectic of acquired habits and a creative personal style of existence. ... The customary level is a general stock of behavior that I share with others ... The creative level is the body as a potentiality for action and as the ability to transform the actual world into a world of possibility" .

Interestingly and sounding rather like a pragmatist, Merleau-Ponty holds that the locus of the virtual body is defined by its task and its situation: "mon corps comme système d'actions possible, un corps virtuel dont le 'lieu' phénomenal est défini par sa tâche et par sa situation. Mon corps est là où il a

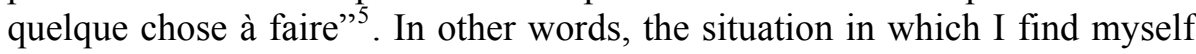

${ }^{1} P d P$, p. $114-118$.

${ }^{2}$ James B. Steeves, "The Virtual Body", art. cit., p. 375.

${ }^{3} P d P$, p. 179.

${ }^{4}$ Ibid., p. 376.

${ }^{5} P d P$, p. 289. 
presents me with certain goals and purposes, but there are multiple possibly indefinitely many - ways in which I can respond. We have here an analogue for the paradox of rule-interpretation. According to Merleau-Ponty, there is the possibility of imagining the world in different ways, there are "interminable reinterpretations to which it is legitimately susceptible" 1 . Of interest here is that, though interminable, the reinterpretations are not arbitrary, but legitimate, suggesting that once more creativity and normativity are intertwined. The ways of seeing the world are always opened up by a particular context, against a particular background, just as we saw in the discussion of the duck-rabbit above.

(iii) Creative imagination and perspective. Referring to The Structure of Behavior, Steeves notes that "[t]he virtual body provides us with the power of choosing and varying points of view" by, for instance, using a mirror or imagining what it is like to see an object from another perspective ${ }^{2}$. Lennon notes that Strawson elucidated the synthetic imagination by discussing what is involved in perceiving a dog and seeing it as "a possible mover and barker". According to Lennon, "the possible moving and barking is part of our immediate and present perception of the dog. This is what Merleau-Ponty was indicating with his claim that the whole problem of the imaginary concerned 'quasi presence and imminent visibility.' ... The way the 'non-present' is woven into the 'present' determines the shape the world has for us" ". This interplay of present and non-present very much also characterizes the rule-following problem. Wittgenstein characterizes the problem as how a rule can determine all of its (future) applications, how, in other words, something present can determine what is not yet present. On the other hand, any (present or past) application exemplifies a rule that is not necessarily itself present. How is it, then, that we are able to learn rules at all based on a finite set of examples, based, that is, on ostension?

My earlier answer to this question was to appeal to the schematic imagination. Merleau-Ponty's account of the embodied imagination with

\footnotetext{
${ }^{1}$ Maurice Merleau-Ponty, "Eye and Mind", art. cit., my italics.

${ }^{2}$ James B. Steeves, "The Virtual Body", art. cit., p. 376.

${ }^{3}$ Kathleen Lennon, "Re-Enchanting the World", art. cit., p. 381. With reference to the lived body Lennon writes, "The character of our perceptual experience therefore takes us beyond what is immediately presented and this interweaving of the elsewhere into current experience is part of what is involved in claiming that the perceived world has an imaginary form ... The character we find the world to have suggests and demands the desiring and sometimes fearful responses we make to it. It is a world we refer to, to make sense of our own modes of existence in relation to it" (p. $382)$.
} 
reference to body schema and the virtual body allows us to detranscendentalize Kant's account. The rule-following problem, on this account, is no longer a paradox, but an immanent part of our being in the world.

I noted above Merleau-Ponty's claim that the virtual body is defined by its task and situation; the body is where it has something to do. This means - and this is no novel claim about embodiment — that the body is always situated, which is to say that one's perspective is always embodied and is always a particular perspective. But now we can see that no perspective is static; rather, it always includes within it the potential for movement and change. In looking at my desk and the computer I'm working on from where I sit, I can imagine what it would look like were I to stand up and move to the other side of the desk, etc. This is crucial for communication. It also sheds light on some of Merleau-Ponty's remarks in Le Visible et l'invisible about knowing others or other bodies.

There, Merleau-Ponty revisits the issue of synesthesia and the synthetic unity of the body. He extends the idea that within my body, the same organ can touch and be touched, as well as be perceived through other modalities (vision, smell) to other bodies.

[Q]uand une de mes mains touche l'autre, le monde de chacune ouvre sur celui de l'autre parce que l'opération est à volonté réversible, qu'elles appartiennent toutes deux ... à un seul espace de conscience, qu'un seul homme touche une seule chose à travers toutes deux ... mes deux mains touchent les mêmes choses parce qu'elles sont les mains d'un même corps ${ }^{1}$.

Again, the body functions to effect a synthetic unity of experience; the body is a prereflexive and pre-objective unity ${ }^{2}$. By extending this synesthesia of the body to our experience of other bodies, Merleau-Ponty thus radically transforms the classic philosophical problem of other minds (in virtue of having overcome the subject-object dichotomy). He asks,

cette généralité qui fait l'unité de mon corps, pourquoi ne l'ouvrirait-elle pas aux autres corps? La poignée de main aussi est réversible, je puis me sentir touché aussi bien et en même temps que touchant... Pourquoi la synergie

\footnotetext{
${ }^{1}$ Maurice Merleau-Ponty, Le Visible et l'invisible, Paris, Gallimard, 1964, p. 183, my italics. Subsequent references as $V I$.

${ }^{2} V I$, p. 184.
} 
n'existerait-elle pas entre différents organismes, si elle est possible à l'intérieur de chacun ${ }^{1}$ ?

In other words, he suggests that, just as we can experience the sensations of touching and being touched, seeing and being seen simultaneously (or, for that matter, of touching and seeing simultaneously), we can see the bodies and actions of others as interconnected with ours; they are not, he says, an absolute mystery to us:

il suffit pour que j'en aie, non pas une idée, une image, ou une représentation, mais comme l'expérience imminente, que je regarde un paysage, que j'en parle avec quelqu'un: alors, par l'opération concordante de son corps et du mien, ce que je vois passe en lui, ... je reconnais dans mon vert son vert... Il n'y a pas ici de problème de l'alter ego parce que ce n'est pas moi qui vois, pas lui qui voit, qu'une visibilité anonyme nous habite tous deux, une vision en général, en vertu de cette propriété primordiale qui appartient à la chair, étant ici et maintenant, de rayonner partout et à jamais, étant individu, d'être aussi dimension et universel.

Avec la réversibilité du visible et du tangible, ce qui nous est ouvert, c'est donc, sinon encore l'incorporel, du moins un être intercorporel, un domaine présomptif du visible et du tangible, qui s'étend plus loin que les choses que je touche et vois actuellement...2.

In embodied conversation with another, the gulf between subject and object, between self and other, disappears. Self and other need not have shared mental representations; one need only look at a landscape together or talk about it together. Shared embodied experience gives rise to intercoporeal being that transcends present experience and thus includes the invisible. It must, therefore, involve the imagination. In a turn of phrase reminiscent of G.H. Mead, Merleau-Ponty then asserts that we become visible to ourselves through the eyes of others ${ }^{3}$.

This way of thinking about our access to the perspectives of others differs from a simulation theory. The latter claims that taking your point of view requires me to think (or act) as if I were you. But on Merleau-Ponty's account, my access to your perspective is immediate, imminent. It is built into the structure of the intercorporeal, of reversibility. In "Eye and Mind", Merleau-Ponty discusses perspective in art at great length. Although he does

\footnotetext{
${ }^{1} V I$, p. $184-185$.

${ }^{2} V I$, p. 185 , italics added.

${ }^{3} V I$, p. 186.
} 
refer to our seeing or creating of a third dimension in a two-dimensional medium as an illusion, he does not put it in terms of "as if" but rather, again, in terms of seeing a two-dimensional picture as having depth - that is, according to what $I$ have argued here, as requiring the schematic imagination that unifies the manifold of perception into a three-dimensional interpretation of a two-dimensional painting. Furthermore, he writes that

the painters knew from experience that no technique of perspective is an exact solution and that there is no projection of the existing world which respects it in all aspects and deserves to become the fundamental law of painting... The language of painting is never 'instituted by nature'; it must be made and remade $^{1}$.

Thus the creative imagination is also at play. Moreover, what applies to the language of painting also applies to communication and meaning. Communication is fallible; we may misunderstand one another (normativity), and, just as for Gadamer, for Merleau-Ponty, meanings are constantly made and remade intersubjectively in dialogue.

It is surely no accident that Merleau-Ponty says that all it takes to share another's reality is to talk to them about what one is experiencing oneself. Communication is immediate; there is no question of having to infer what you mean by what you say, as he stresses when discussion language as expression, since our experience is embodied and that occurs in what Merleau-Ponty describes as the "intercorporeal" field or domain of experience.

The meaning of words rests on what Merleau-Ponty calls "gestural signification" ". When I am abroad, he writes, I begin to understand what words mean by their place (role) in a context of action (I would say interaction) and by participating in common life $^{3}$. This most basic form of linguistic meaning brings together the ideas of embodiment and practice. Interestingly, and consonant with what Gadamer says, Merleau-Ponty notes that the meaning of a literary work or poetry is less constituted (moins fait) by shared meanings of words than it contributes to modifying them ${ }^{4}$; it is, we might say echoing Heidegger, meaning-constituting. Emotional meaning (sens émotionnel) is gestural meaning (sens gestuel) and is essential to

\footnotetext{
${ }^{1}$ Maurice Merleau-Ponty, "Eye and Mind", art. cit., p. 135.

${ }^{2} P d P$, p. 209.

${ }^{3} P d P$, p. 209.

${ }^{4} P d P$, p. 209.
} 
poetry ${ }^{1}$. Merleau-Ponty rejects an imagistic or representational account of language, saying that there is no need for verbal image, just as there is no need for a representation of movement before moving/in moving ${ }^{2}$. Words are like the blind person's cane: instruments that are really extensions of the body. Thus, when in The Phenomenology already he writes, "C'est par mon corps que je comprends autrui", , he anticipates the idea of intercorporeal reversibility that he elucidates in Le Visible et l'invisible. At the same time, this bodily intersubjectivity is for him more primordial than linguistic intersubjectivity.

The fact that Merleau-Ponty starts with embodiment allows him to incorporate emotional meaning from the outset as fundamental to linguistic meaning. It also means, however, that "complete meaning is never translatable from one language to another"4; that is, it represents Gadamer's individualizing tendency in language that resist translation.

\section{Conclusion}

I hope to have shown that the imagination and normativity are integral to language and communication and stand in complex relationships to one another. The schematic, creative, and embodied imaginations play important roles. The schematic imagination mediates between the semantic rule and its application and thus helps explain how a set of examples exemplifies a given rule to us. It is therefore part of an account of normativity itself. The creative imagination generates novel meanings and stands in a dialectical relation to normativity. The embodied imagination detranscendentalizes the Kantian account of the schematic imagination and makes it possible to transcend cognitivist accounts and to acknowledge affective dimensions of meaning. Last but not least, incorporating embodied imagination opens up the possibility of thinking about perspective-taking and intersubjectivity in new ways.

${ }^{1} P d P$, p. 218.

${ }^{2} P d P$, p. 210.

${ }^{3} P d P$, p. 216.

${ }^{4} P d P$, p. 218. 


\section{References}

Butler Judith, 1997, Excitable Speech, New York, Routledge.

Currie Gregory and Ravenscroft Ian, 2002, Recreative Minds, Oxford, Oxford University Press.

Davidson Donald, 2005, "A Nice Derangement of Epitaphs", in Truth, Language, and History, Oxford, Oxford University Press, p. 89-107.

Derrida Jacques, 1988, Limited Inc., Evanston (IL), Northwestern University Press.

Gadamer Hans-Georg, 1999, "Semantik und Hermeneutik", Gesammelte Werke, vol. 2, Tübingen, Siebeck.

Gadamer Hans-Georg, 1999, "Vielfalt der Sprachen", Gesammelte Werke, vol. 8, Tübingen, Siebeck.

Kant Immanuel, 1998, Kritik der reinen Vernunft, Berlin, Akademie Verlag.

Lennon Kathleen, 2010, "Re-Enchanting the World: The Role of Imagination in Perception", Philosophy: The Journal Of The Royal Institute Of Philosophy, vol. $85, \mathrm{n}^{\circ} 333$, p. $375-389$.

Merleau-Ponty Maurice, 1945, Phénoménologie de la perception, Paris, Gallimard.

Merleau-Ponty Maurice, 1964, Le Visible et l'invisible, Paris, Gallimard.

Merleau-Ponty Maurice, 1993, "Eye and Mind", in Galen A. Johnson (ed.), MerleauPonty's Essays on Painting, Evanston, Northwestern University Press.

Nichols Shaun, 2006, "Introduction", in Shaun Nichols (ed.), The Architecture of the Imagination, Oxford, Oxford University Press.

Pettit Philip, 2002, Rules, Reasons, and Norms, Oxford, Oxford University Press.

Pettit Philip, 2002, "The Reality of Rule-Following", in Alexander Miller and Crispin Wright (eds.), Rule-Following and Meaning, Montreal, McGill Queens University Press.

Ricœur Paul, 1991, "Word, Polysemy, and Metaphor: Creativity in Language", in Mario J. Valdés (ed.), A Riccur Reader: Reflection and Imagination, Toronto, University of Toronto Press.

Steeves James B., 2001, “The Virtual Body: Merleau-Ponty's Early Philosophy of Imagination", Philosophy Today, p. 370-380.

Tierney Nathan, 1994, Imagination and Ethical Ideals, Albany, SUNY Press.

Wittgenstein Ludwig, 1958, Philosophical Investigations, Oxford, Blackwell. 